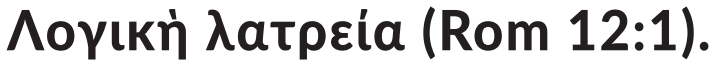 The Pauline Idea of Worship between the Hebrew and Hellenistic Worlds
}

\section{MATTEO CRIMELLA}

Theological Faculty of Northern Italy, Milan

matteo.crimella@gmail.com, ORCID: 0000-0002-0425-3211

\begin{abstract}
This essay focuses on a passage from Paul's Letter to the Romans, in particular on an ex-

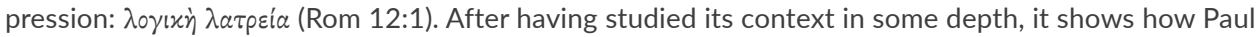
operates in a dual direction: the apostle removes from the expression any semantic link bound up with worship; he also attributes to it a profane semantic. Paul does not intend to oppose the two worships, Jewish and Christian. His words imply that, like ancient Israel before them, the Christian believers should also be distinguished for their worship. Christian worship is conceived differently. It is far from being a spiritualization of worship. Such a reduction is excluded by the object of the sacrifice, "your bodies." Paul operates in two directions: on the one hand, he avoids the trap of supersessionism with regard to Jewish worship; on the other hand, he excludes a spiritualization (or interiorization) of Greek religious practices. Paul's language is distinct both from the grand tradition of Israel and from the Hellenistic world.
\end{abstract}

Keywords: $\lambda$

\section{A Letter in Greek}

Like the other writings of the New Testament, we possess the Letter to the Romans in Greek, and, in the opinion of all the experts, it was thought up and dictated (cf. Rom 16:22) by Paul, precisely in the language then current in the Eastern part of the Roman Empire. The choice of Greek was almost de rigueur, but not without certain consequences. In fact, expressing oneself in that language involved the responsibility of taking up a vast and fascinating culture with the possibility of allowing oneself to be dominated by its models of thought. Paul was certainly not the first to formulate his ideas in the language of Homer which was later spread by Alexander of Macedon around the whole of the Mediterranean basin. The Hebrew Bible had already been translated into that idiom, and it was precisely in that same language that not a few Jews of the time wrote to the extent that, in the middle of the I century A.D. 
(the period when Paul composed Romans) one could already speak easily of a not negligible Jewish literature in Greek. ${ }^{1}$

In this brief essay, we shall focus our attention on a celebrated passage, better, on

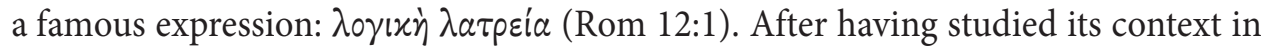
some depth, we would like to show how Paul operates in a dual direction: on the one hand, the apostle removes from the expression any kind of semantic link bound up with the worship; on the other hand, he attributes to it a profane semantic. ${ }^{2}$ Naturally, we have to ask about the consequences of this double procedure and what it can indicate concerning that complex problem of the relation of Christianity with the Hellenistic world. ${ }^{3}$

\section{A Parecletic Development}

Many commentators ${ }^{4}$ on the Letter to the Romans recognise that, from chapter 12 , there begins a paraenetic development or, to use even more precise language, a paracletic one. ${ }^{5}$ If we analyse the rhetorical strategy of the letter, it emerges that, after an expansive salutation (cf. Rom 1:1-7), the apostle concludes his exordium (cf. Rom 1:8-17) with the expression of his fundamental theological thesis, the propositio (cf. Rom 1:16-17). Here, he offers a general definition of the gospel, not in terms of content but, rather, of formal constitution. He does not say what is or what ought to be the object of his proclamation but insists on the importance and on the fundamental character of the proclamation as such (it is clear, nevertheless, that the reference is to the Christian proclamation); evangelisation is an event that lies close to his heart. Paul does not start off from the historical past of the Christ-

1 Cf. Adrados, Historia de la lengua griega, 184-189; Usener, "Zur Sprache der Septuaginta," 40-51.

2 Jean Noël Aletti (La Lettera ai Romani, 111) writes: "[I] cristiani provenienti dal paganesimo non potevano più fare ritorno ai templi pagani, né era loro consentito, in quanto incirconcisi e non ebrei, entrare nel tempio di Gerusalemme e unirsi alle feste dei loro fratelli di origine ebraica. [...] Paolo fa capire loro che non sono affatto penalizzati, che non gli manca nulla, dato che la loro stessa vita è unofferta superiore ad ogni altra."

3 For a documented discussion, cf. Markschies, Hellenisierung des Christentums.

4 On this question, there is no unanimity. For some, this is the beginning of the paraenetic part of the letter; for others, Rom 12:1 represents the beginning of another letter which later merged with Romans (on this whole question, cf. the survey of Michele Marcato [Qual è la volontà di Dio, 61-63]).

$5 \quad$ Antonio Pitta (Lettera ai Romani, 417) writes: "Per importanti motivazioni abbiamo intitolato questa unità letteraria come paràclesi e non come parenesi paolina, contrariamente alla trattazione comune di $\mathrm{Rm} 12,1$ - 15,13. Di fatto, mentre nel NT è raro l'uso del verbo parainein (2 volte: At 27,9.22) e il sostantivo parainesis non è mai utilizzato, sono diffusi i corrispondenti parakalein e paraklēsis. [... M] entre parainein e parainesis significano soltanto esortare o incoraggiare, i termini paraklesis e parakalein assumono significati più ampi, oltre a esortare, come consolare (cf. 2Cor 1,3-4) e perorare la causa di qualcuno in contesti giudiziari (cf. 1Gv 2,1)." 
event but from the here and now of evangelisation. The whole letter is thus placed under the standard of the concept of "gospel." The probatio is extensive and subdivided into three stages: Hebrew and Greek have been justified by faith alone (cf. Rom 1:18-4:25); whoever has received the justice of God in faith has the new life in the Spirit (cf. Rom 5:1-8:39); God has manifested his justice towards Israel too (cf. Rom 9:1-11:36). This first part of the letter concludes with the recognition that God wishes to have mercy (the verb used is $\varepsilon^{\prime} \lambda \varepsilon \dot{\varepsilon}(\omega)$ on every person (cf. Rom 11:30). The second, paracletic, part (cf. Rom 12:1-15:13), takes up the very foundation of the Christian life, that is, the mercy of God (here, however, the word used is oixtıpuós; cf. Rom 12:1).

The link between the incipit of the second section and the first part has been much discussed by exegetes. Not a few commentators take their stance from the conclusive particle "therefore (oṽv)" (Rom 12:1) ${ }^{6}$ and on the theme of mercy. ${ }^{7}$ Others, though, object, claiming that Paul is not speaking explicitly of justice and justification; moreover, the particle oũv could have a generic value and indicate only the passage to a new subject. Thus, by varying the terminology about mercy (from $\dot{\varepsilon} \lambda \varepsilon \dot{\varepsilon} \omega /$ $\varepsilon$ Ė $\varepsilon \circ \varsigma$ to oix vious section ${ }^{8}$ so that the new section would have a self-standing paracletic character.

The intermingling of the formal-literary and logico-contentual dimensions has to be recognised as essential for an adequate analysis of the Pauline Epistles since it appears problematic, at the very least, to focus on the simple inventio of the rhetorical devices employed by the apostle, which have been determined from the starting point of ancient treatises (or even from modern manuals), but without grasping the articulation of his thought.

\section{A Theological Reversal}

First of all, it is necessary to highlight that our passage is the end point of an argument which has been created within the letter. We are, therefore, among those who hold that the paraclesis is closely linked to the so-called doctrinal section. In fact, although

6 Douglas J. Moo (The Epistle to the Romans, 748) claims, for example: "Therefore' must be given its full weight: Paul wants to show that the exhortations of 12:1-15:13 are built firmly on the theology of chaps. 1-11".

7 Pitta (Levevangelo di Paolo, 267) notes: "Nel caso di 12,1 - 15,13 il motivo della misericordia divina, accennato in 11,30, torna in 12,1, anche se con termini diversi: nel primo caso si tratta della misericordia gratuita di Dio, nel secondo della sua compassione per gli uomini che interpella l'offerta dei loro corpi. Pertanto, si tratta di un [sic!! etica consequenziale che salvaguarda l'eccedente gratuità della giustificazione in Cristo."

8 Cf. Evans, "Romans 12.1-2," 9-10. 
the section which begins here is exhortatory, that does not take away from the fact that the paraclesis is well inserted into the preceding kerygmatic exposition. The argument convincing us is not so much the question of oũv as a more careful consideration of the whole of what Paul is saying. The study of the semantics of our passage shows that it ties together a series of threads which Paul has drawn on until now in his writing. This discursive network shows the nature of the way of the believer. ${ }^{9}$

There is, first of all, a theological reversal by means of the reprise of the vocabulary typical of the first part of the letter (cf. Rom 1:18-3:20) which, however, is given a positive sense. The context of Rom 1:18-3:20 sketches a picture of a humanity which refuses to recognise the works of God. Men use their "bodies $\left(\sigma \omega \omega^{\prime} \mu \alpha \tau \alpha\right)$ " (Rom 1:24) in a way that dishonours them. They have perverted God's truth with a lie, worshipping ( $\dot{\lambda} \lambda \dot{\tau} \tau \rho \varepsilon v \sigma \alpha \nu$ ) the creation rather than the Creator (cf. Rom 1:25). Since they did not consider the full knowledge of God worth having, God handed them over to their "base mind ( $($ ovv)" (Rom 1:28). The condemnation is universal. It affects both Jews and Greeks alike: the Jew knows the "will ( $\theta \dot{\varepsilon} \lambda \eta \mu \alpha)$ " (Rom 2:18)

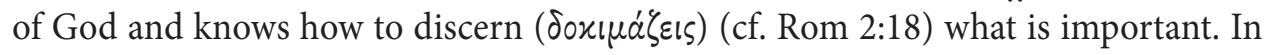
fact, however, he nullifies his superiority through his infidelity. In the first part of the letter, this vocabulary paints a black picture, one of justice which is forensic and not evangelical. In chapter 12 , this same vocabulary is reprised with a positive value. The "bodies" which lead to dishonour (cf. Rom 1:24) become "bodies ( $\sigma \omega \dot{\omega} \mu \tau \tau \alpha)$ " (Rom 12:1) offered as a living sacrifice; the worship of the creation (cf. Rom 1:25) is displaced by a "worship ( $\lambda a \tau p \varepsilon i \alpha \nu)$ " in the order of the lógos (cf. Rom 12:1); the base

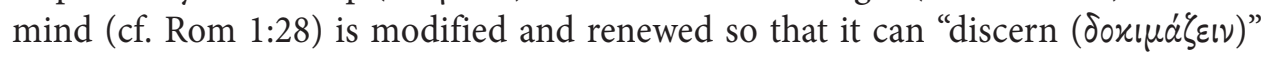

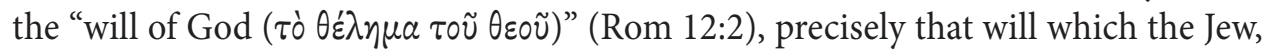
the recipient of Paul's apostrophe (cf. Rom 2:18), believed that he knew.

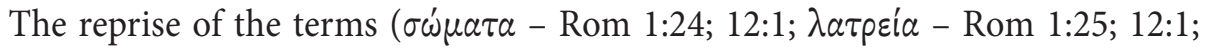

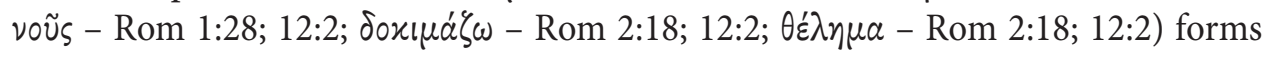
part of a rhetorical strategy within a discursive argument which is meant to provoke a change in the reader's understanding of himself. He passes from sin and unbelief to grace and faithfulness. But how can such a change come about?

After tracing a dark panorama (cf. Rom 1:18-3;20), Paul changes key completely: God reveals his justice independently of the Law by freely justifying those who believe in him (cf. Rom 3:21-5:21). Penna comments thus: "Passing from v. 20 to v. 21 of Rom 3 is like crossing a threshold, passing through a watershed, overcoming a disparity in height with a decisive leap, a leap which returns to recover the height of the theme set out in the propositio, 1:16-17, beginning again on that same height." ${ }^{10}$ The condemnation which weighed on humanity has been removed, making possible a life in grace. Thus, the believer comes to a new understanding of his own existence.

9 Cf. the study of Danielle Jodoin ("Rm 12, 1-2 une intrigue discursive").

10 Penna, Lettera ai Romani, 229. 
Whoever has received in faith the manifestation of the justice of God, revealed by the gospel, finds himself before a new possibility which takes on the face of responsibility. "Dead with Christ" (Rom 6:8) through baptism, the justified believers are no longer under the slavery of the Law and sin but under the liberating lordship of the grace of Christ, who acts in them through the Spirit (cf. Rom 8).

The frequent use of the verb rapi $\sigma \tau \eta \mu$ ("offer," 5 times in Rom 6) marks another crucial moment in the way of the believers: they must conform their existence to the new state acquired in justification. Two types of offering are mentioned:

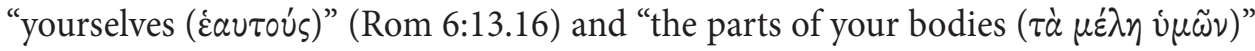
(Rom 6:13.19). Whereas the offering of the "parts of the body" is always in tension between a negative past and a positive present, the offering of "yourselves" seems to be free from this opposition and is always positive. The same verb, $\pi \alpha \rho i \sigma \tau \eta \mu$, is employed in our text. This time, however, the object of the offering is no longer the "members $\left(\mu \dot{\varepsilon}^{\prime} \lambda \eta\right)$ " but the "bodies ( $\left.\sigma \omega^{\prime} \mu \alpha \tau \alpha\right)$ " (Rom 12:1).

The term $\mu \dot{\varepsilon} \lambda \eta$, furthermore, indicates two distinct realities: both the parts of a person's body and the parts of the body of Christ, that is, the "community." It is somewhat singular that, before our passage in Rom 12:1-2, $\mu \dot{\varepsilon} \lambda \eta$ always indicates the parts of the body (cf. Rom 6:13.19; 7:5.23); afterwards, however, it designates those who belong to the Christian community (cf. Rom 12:4.5). As we have already observed in connection with the verb $\pi a p i \sigma \tau \eta \mu l$, the uses of the term $\mu \varepsilon^{\prime} \lambda \eta$ also reveal a tension between justice and injustice (cf. Rom 6:13); between impurity and holiness (cf. Rom 6:19); between the law of sin and another law (cf. Rom 7:5.23). Yet, after our passage, the "members" indicate the parties of reality that is completely united, one that forms a single body in Christ (cf. Rom 12:4.5). A similar semantic change is made possible by the radical transformation spoken of in Rom 12:1-2. In other words, the offering of those members that are now free from tension, namely of the body as a living sacrifice, manifests adhesion to God. By means of the semantic change from a "body vowed to death because of sin" (Rom 8:10) to the bodies offered "as a living sacrifice" (Rom 12:1) and from the "offering of the members" (Rom 6:13) to the offering of the bodies (cf. Rom 12:1), the believers participate in the same transformation.

These observations about the semantics enable us to draw a first consequence. The reprise of a series of key-words from the previous argument evokes in the reader the fundamental steps which Paul has made him take by expounding his gospel, emphasising without ceasing the gratuitous nature of God's gift and of his mercy for everyone. If Paul has argued convincingly, he now intends to evoke a response in the reader. Christian action can only be consistent with what has been laid down, according, that is, to the rule of faith. The emphasis is clearly anthropological in that Paul does not resume the previous theological "treatment" (in fact, there is none of the vocabulary typical of the first part: "gospel," "salvation," "faith," "revelation," "power" and "justice of God"); rather, the focus is on the life of the baptised, transformed by grace and power of the Holy Spirit. 


\section{The Paraclesis}

A second observation concerns the theme of the paraclesis. Before issuing the command to offer their bodies, Paul introduces a prepositional complement: "through

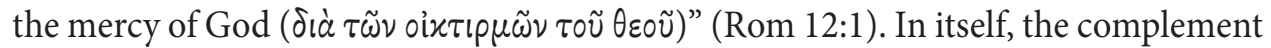
could be understood in an adverbial sense, emphasising the urgency of the request. In fact, the singular nature of the expression draws attention to a theological purpose. The commentators are divided into two groups: for some, this expression recalls the whole of the first complex of the letter (chapters 1-11); for others, instead, only the final section (chapters 9-11). ${ }^{11}$ The question is the following: how to interpret

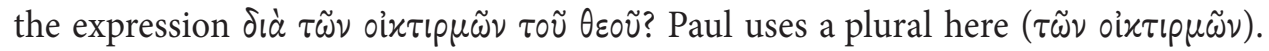
This is usually explained as a Septuagintism, ${ }^{12}$ and so with the value of an intensive singular. ${ }^{13}$ However, the rarity of the expression requires further investigation. The term oixtipuós and the verb oixtipw occur about seventy times in the Greek version of the Bible. From various texts (cf. Exod 33:19; Zech 12:10; 3 Macc 5:51), the revelatory value of mercy emerges: the Lord has manifested and manifests his gift of himself to the people of Israel by freeing them from slavery. Later, the Psalter (cf. Ps 50) sings the trust of the people in the Lord who does not treat them according to their sin but pardons them. The same idea is developed in the penitential prayers (cf. Ezra 9; Neh 9; Dan 9).

Paul makes his own all the potentiality of the term oixtipuós as it is attested in the Septuagint. However, before considering Rom 12:1, we must turn briefly to the first part of the letter. Two texts are crucial in this regard: Rom 9:14-16 and Rom 3:21-26. In Rom 9-11, Paul tackles the mystery of Israel, the election of a special people by God, the rejection of the proclamation of the gospel by some. To do this, he places himself in a position that is really singular. As Dunn incisively puts it: "the blessings of the gospel (to all) are the blessings of Israel; and yet they remain Israel's blessings." ${ }^{4}$ Paul, that is, does not immediately (in Rom 9:15) defend God's freedom to preserve some and abandon others. The divine identity is pictured in terms of pure mercy. Moreover, the reference to the Lord's words to Moses reveals that Paul is probably alluding to the context of the conversation which took place after the rebellion and the idolatrous act with respect to the golden calf (cf. Exod 32:1-25). It is quite clear, therefore, that God's revelation to his people is his self-manifestation of his mercy and compassion. Thus, the quotation of Exod 33:19 in Rom 9:15-16 underlines the revelatory aspect of mercy while the grace of pardon is implicit. However, in Rom 3:21-26, the passage which represents the theological acme of the letter,

\footnotetext{
A precise list of the positions and authors is provided by Gupta ("What 'mercies of God'?", 82, n. 3).

Cf. Blass - Debrunner - Rehkopf, Grammatik des neutestamentlichen Griechisch, $\$ 142$.

Cf. Romano Penna (Lettera ai Romani, 811-812), who records various examples and also quotes the exact translation of the Vulgate, "per misericordiam Dei."

Dunn, Beginning from Jerusalem, 910.
}

14 
the three dimensions of mercy emerge in all their force: firstly, the revelation of God himself (cf. Rom 3:21) in the historical event of Christ; second, the redemptive aspect: God has carried out the "redemption (å $\left.\pi 0 \lambda v^{\tau} \tau \omega \sigma / \varsigma\right)$ " (Rom 3:24) precisely by means of Jesus so that the term is a powerful evocation of the image of the Exodic liberation, but, in the context, has a Christological colouring; and, finally, Paul refers the effect of pardon to the justice of God.

At this point - and only at this point - we can return to Rom 12:1. When Paul exhorts his readers to offer their bodies, the commentators recall that the term $\sigma \tilde{\omega} \mu \alpha$ indicates the person as a whole. However, we must not forget that, in the Letter to the Romans, Paul has always spoken of the body as under the dominion of sin. Starting from the first chapter, the apostle describes the corruption of the body (cf. Rom 1:24); the body of Abraham is described as "already dead" (Rom 4:19); chapter 6 speaks of a "body of sin" (Rom 6:6) subjected to slavery (cf. Rom 6:12). The "I," who is the subject of chapter 7, is hoping for liberation "from this body of death" (Rom 7:24). Finally, in the chapter devoted to the Spirit, Paul recalls that a new life has been given to this "mortal body" (Rom 8:11) so that the power of sin has been eradicated (cf. Rom 8:13). On this basis, precisely by appealing to mercy, Paul can exhort the believers, liberated from the yoke of sin and death, to enjoy their new condition. Moreover, it is precisely by evoking the image of the Exodus that Paul reflects on the impact of the Christ event: the Israelites passed from slavery to freedom, and, journeying in the desert, they learned to serve the Lord. The verb used in the Greek version of the book of Exodus to indicate the service of God is $\lambda \alpha \tau \rho \varepsilon v \omega^{\prime} \omega$ (cf. Exod 3:12), a verb closely related to the substantive $\lambda \alpha \tau p \varepsilon i \alpha$ (cf. Rom 12:1). From this it follows that the believers are called to offer their bodies, not as an object of worship (cf. Rom 16:18) but as an organ of worship, that is, through their commitment to God.

Thus, the worship of which the apostle speaks is the end point of the salvific work willed by God and carried out by Jesus Christ, that work which the pregnant and rare term oixtipuós evokes through its multifaceted dimensions.

\section{Sacrificial Terms}

The response which Paul intends to provoke is meant to involve the whole being: spirit, intelligence, will. Surprisingly, the paraclesis is expressed in sacrificial terms. That has to be understood as having a double matrix: Jewish and pagan. Paul's language has the power to evoke both backgrounds: the biblical and the Greco-Roman.

The paraclesis is composed of a rather complex exhortation (cf. Rom 12:1) and a pair of imperatives (cf. Rom 12:2) whose range is general. It is surprising that the apostle develops an original concept of worship in order to lay down the pro- 


\section{MATTEO CRIMELLA}

gramme of the Christian life. The employment of a sacrificial language is somewhat singular in that Paul rarely has recourse to cultic images to speak of Christ and the Christian. At times though, he uses metaphors drawn from precisely that world in order to delineate aspects of the believing life (cf. Phil 4:18; 2 Cor 8-9). It is worth the trouble of pausing to examine terms indicating worship since this is the heart of the present paper: they are at the centre of a notable scholarly discussion.

Paul invites his readers to offer their bodies, namely, themselves, as sacrificial victims. The exhortation intends to involve the whole person, that is, daily existence

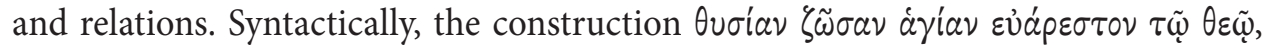

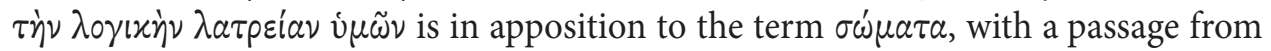
the plural to the singular, something which could signal the corporate dimension of the presentation. ${ }^{15}$ The metaphorical nature of the expression is clear in that Christians do not offer sacrifices in the literal sense; that is, they do not burn animals

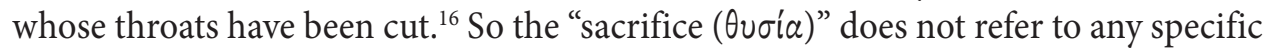
forms of worship but involves the bodies of the people concerned, that is, their existence. The emphasis is wholly on the interaction between the person and the world. The apostle then makes use of three adjectives corresponding to the sacrificial meta-

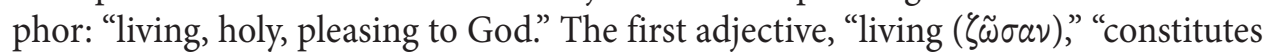
a clear oxymoron," ${ }^{17}$ precisely because the sacrifice consists of the killing of an animal whereas the emphasis here is on human life; the second, "holy ( $\left.\dot{\alpha} \gamma^{\prime} \alpha \nu\right)$ ), is employed regularly for the description of sacrifices, even if implying here the offering of the offerers themselves to God, that is, being set apart from what is profane in order to be dedicated to the service of the Lord. The final expression, "pleasing to God ( $\varepsilon \dot{u} \alpha \dot{\rho} \varepsilon \sigma \tau o v$ $\tau \tilde{\omega} \theta \varepsilon \tilde{\omega})$ )" recalls the idea of the pleasant odour which rises to heaven (cf. Lev 1:13.17).

The description of this "cultic service ( $\lambda \alpha \tau p \varepsilon i \alpha)$ " in a metaphorical sense ( $\lambda \circ \gamma\left(x \eta^{\prime}\right)$ is really singular. The term $\lambda \alpha \tau \rho \varepsilon i \alpha$ signifies "service" but it is often used in a religious and cultic sense both in classical Greek ${ }^{18}$ and in the Septuagint. ${ }^{19}$ However, the adjective (which does not appear in the Septuagint) is crucial; it occurs only here and in 1 Pet 2:2 where it describes that $\lambda$ oyıxóv "milk" which nourishes the newly baptised

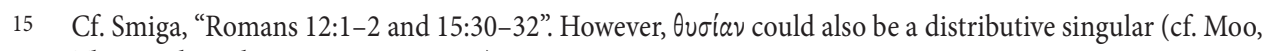
The Epistle to the Romans, 750, n. 24).

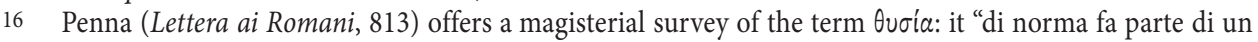
contesto sacrale e serve a designare lo sgozzamento di un animale, di cui una parte viene bruciata in onore degli dèi e un'altra viene consumata dagli offerenti in un banchetto."

17 Penna, Lettera ai Romani, 814.

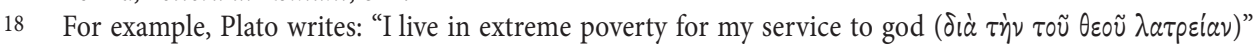
(Apologia 23c). There is also an interesting text by Philo: "we conceive of the Samuel of the Scripture, not as a living compound of soul and body, but as a mind which rejoices in the service and worship of God

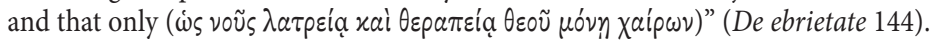

19 There are nine occurrences: Exod 12:25.26; 13:5; Josh 22:27; 1 Chr 28:13; 1 Macc 1:43; 2:19.22; 3 Macc 4:14. The verb $\lambda \alpha \tau$ év $\omega$ is much more frequent (98 times); cf. Exod 23:25: "You shall serve the Lord your God." 
who are portrayed as new-born babes. This is clearly milk in a metaphorical, not a material sense. The same goes for Rom 12:1. However, light is shed on this adjective by the Hellenistic world ${ }^{20}$ where it recurs with a certain frequency. Philo writes: "What is precious in the sight of God is not the number of victims immolated but the true

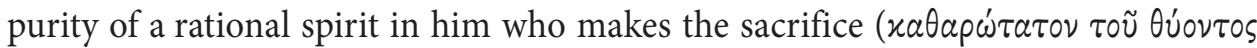

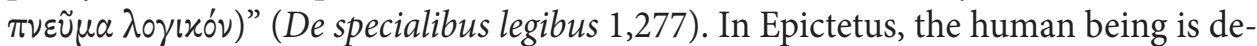

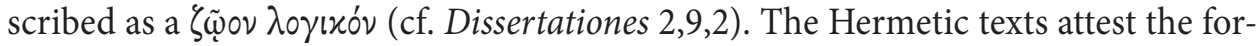

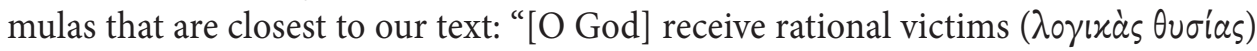
pure from the soul and the heart raised to you" (Corpus hermeticum 1,31). What we have here, therefore, are non-material offerings which rise from within people, consisting, perhaps, of silent adoration. In addition: "Through me, receive everything

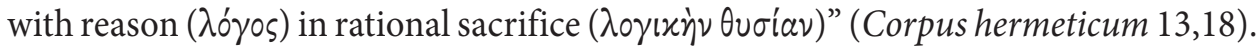
To these occurrences we must add others originating, from Greek-speaking Jewish circles. In the Testament of Levi, the angelic worship around the throne of God is described thus: they "offer to the Lord a fragrance of good perfume, a reasonable and bloodless victim ( clares: "[God] somehow fashioned a house or a sacred temple for the rational animal ( $\psi \cup x \tilde{\eta} \varsigma \lambda \circ \gamma(x) \tilde{s})$ ), which man was to have carried within himself as a sacred image, the most Godlike of all the images" (De opificio mundi 137).

On the lexical plane, there is actually nothing equivalent to $\pi \nu \varepsilon u \mu a \tau i x o ́ s$ (Rom 7:14), the adjective Paul utilises for the pneumatological perspective. If he had wanted to indicate it here, he would certainly have used it. Instead, $\lambda \circ \gamma\left(x y^{\prime}\right.$ could have been suggested to him from the Greek environment to indicate the kind of worship that was in harmony with human nature, that was "logical." So one could think of linking it with the metamorphosis of the voũ s of which Paul speaks in Rom 12:2. In this case, a worship would be being indicated which was not just suitable to the natural "rationality" of human beings but, rather, to their minds transformed by the soteriological action of God. The next verse, Rom 12:2, seems to be specifying this "reasonable worship" objectively as nonconformity and, above all, metamorphosis. The transforming eschatological newness has erupted into history in Christ, as Paul recalls elsewhere ("the old has gone away; behold, the new has arisen" [2 Cor 5:17]). This is translated into an active "being renewed" of the interior and mental sign of the person (voũs), which enables a conscious action in conformity with the will of God and the pursuit of the good. The adjective has been (and is) translated with "spiritual," but, undoubtedly, its sense is rendered better by the adjectives "rational," "logical," "sensible," "reasonable" or the periphrasis: "what has to do with the reason," or else: "suitable, decent." 21

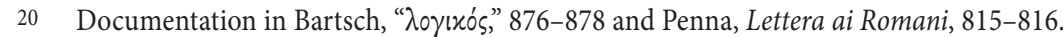

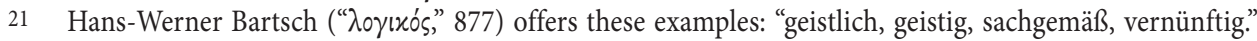
Massimiliano Palinuro ("Rm 12:1-2: le radici dell'etica paolina," 167) explains: "Le versioni antiche 


\section{MATTEO CRIMELLA}

If one part of the vocabulary employed here - namely, the verb "offer," the term "sacrifice" and then the adjectives "holy," "pleasing to God" and the term "worship ( $\left.\lambda \alpha \tau \varepsilon^{\prime} \alpha\right)$ " - is a clear echo of cultic language, the addition of the terms "your bodies," "living" and "in the order of the lógos", beyond the invitation to transformation and nonconformity, makes clear that the Pauline use of the cultic metaphor is an attempt to break with the patterns of thought familiar to the reader. ${ }^{22}$ It is precisely here, however, that the debate rages.

For not a few interpreters, ${ }^{23}$ Paul is playing here on the contrast between Jewish and Christian worship by actually providing a new definition of the cultic category. At the heart of this interpretation there is the focus on the contrast between the Jewish and Christian systems, starting out from the context of the letter. In effect, Paul has just finished discussing (in chapters 9-11) the problem of Israel, and, only in that context, he has employed the term $\lambda a \tau p \varepsilon i a$ (cf. Rom 9:4), precisely with reference to Jewish rites. However, as we have shown, the reprise of some semantic fields from the letter as a whole establishes a broader link, not only with Rom 9-11. ${ }^{24}$ In other words, it cannot be the immediate context alone which is decisive; better a reference to the broader structure of the whole of the Letter to the Romans.

For example, the reading of a Lutheran stamp opposes the Gospel and the Law. Hence the idea that Paul rejects his Jewish past and with it the related forms of worship. Not infrequently, such an opposition has been emphasised from the starting point of the apostle's own texts (for example, Phil 3:7-8.13). However, a more careful study seeks to avoid falling into the trap of such a preconceived interpretation. It seems, in fact, that Paul's problem with Judaism is nothing to do with the cultic system of Israel but focuses, first and foremost, on the substantial rejection of Jesus by many Jews, and then on the insistence of the Jewish Christians on the need for pagans to become Jews in order to enter the people of God. Whenever Paul expresses himself critically over the Law or the Jews, these aspects emerge. On the other hand, it is more difficult to be certain that Paul rejected the Jewish worship entirely when he became a Christian. Within the authentic epistles, the very few references to the sacrificial worship of Israel are not critical but, rather, neutral (cf. 1 Cor 9:13; 10:18). The statement that

e quelle moderne sono accumunate dalla difficoltà di rendere adeguatamente il significato e oscillano tra 'spirituale,' 'razionale' e 'verbale." Also Ian W. Scott ("Your Reasoning Worship," 532) comes to similar

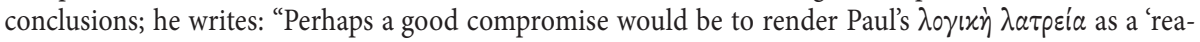
soning act of worship."

22 Cf. Peterson, "Worship and Ethics in Romans 12," 272-276.

23 Cf. Thompson, "Romans 12.1-2 and Paul's Vision for Worship."

24 Making the most of the expression $\delta i \dot{\alpha} \tau \tilde{\omega} \nu$ oix

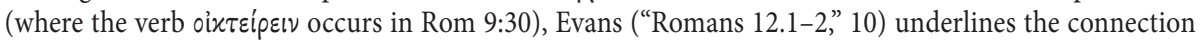
with chapter 8. He speculates: "If a connection is being sought, the initial injunction of the parenesis 'to present your bodies a living sacrifice' might suggest a resumption (though without any mention of the Spirit) of what had been said in ch. 8 about the quickening and redemption of the bodies of Christians." 
"Christ, our Passover, has been sacrificed" (1 Cor 5:7) is undoubtedly very full of meaning but it does not challenge the original value of the practice. Moreover, there are no certain data to show that Paul did not take part in the worship in the temple at Jerusalem. On the contrary - although the statement is from Luke and not from Paul - the evidence of Acts reveals the opposite (cf. Acts 21:15-26; 24:17-18). To make a neat opposition between Judaism and Christianity in Paul's time is wholly unwarranted; equally so is the denial of the importance of the temple in Jerusalem for the Christian communities as well as for Paul himself.

There is a still more decisive factor which prevents us from considering the Pauline statement as a rejection of the forms of Jewish worship. In the rhetorical structure of the Latter to the Romans, faith in Jesus prevents the thought that it is necessary to become Jews in order then to be Christians. On the other hand, though, Paul insists that the majority of the gentiles, who have become believers in Rome, must not assume an air of superiority towards the Jews (cf. Rom 11:13-25). He recalls that "the gifts and the call of God are irrevocable" (Rom 11:29) and he does not dare to go any further with regard to the worship.

To grasp what Paul intends to say at the beginning of the paracletic part, we have to return to the beginning of the letter, to Rom 1:18-32, that is, to those statements which follow immediately on the so-called propositio. It is not necessary to be surprised if, when describing the behaviour of humanity in Christ, Paul wishes to echo the language which he has already used to describe sinful humanity. In other words, the beginning of the second part of the letter is calling for participation in the reversal of that movement towards the bottom described in the first part. The apostle had begun the corpus of his writing by emphasising that the root of the sin which led to the revelation of the wrath of God was the refusal to glorify and thank God

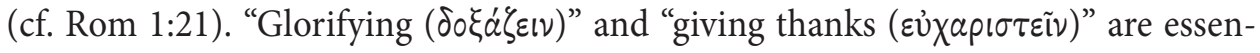
tially acts of worship as is confirmed by the fearful exchange of which the apostle speaks twice: "They exchanged the glory of the immortal God for images resembling mortal man, birds, quadrupeds and reptiles" (Rom 1:23); and, shortly afterwards: "They exchanged the truth of God for a lie and worshipped and served the creation instead of the Creator" (Rom 1:25). However, the outcome of this does not signify in itself the end of the worship, despite its deviation in its dealings with other realities than God. If Paul had used technical cultic terms frequently, the link between

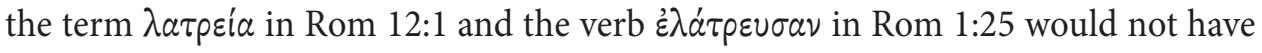
any special significance. However, as we know, the apostle rarely employs such language. The verb $\sigma \varepsilon \beta a ́$ 'o $\mu_{\alpha l}$ ("worship," or also "adore") in Rom 1:25 is a hapax legom-

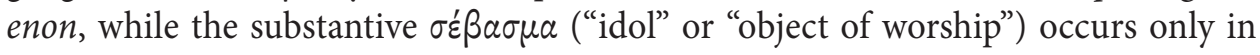
2 Thess 2:4. The verb $\lambda \alpha \tau \rho \varepsilon \dot{\omega} \omega$ ("serve" in a religious context) occurs in Rom 1:9.25 and in Phil 3:3. It is precisely the rarity of the use of this terminology that indicates the link between the beginning of Rom 12 and Rom 1 . 


\section{MATTEO CRIMELLA}

While men refused to offer God true worship, their reasonings became empty (cf. Rom 1:21) and their dull heart was darkened (cf. Rom 1:22). The consequence

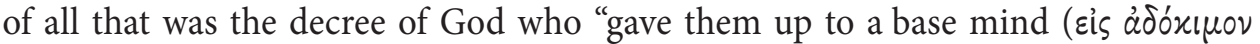
voũv)" (Rom 1:28). In the light of this discourse, Paul's call for a "renewal of the mind

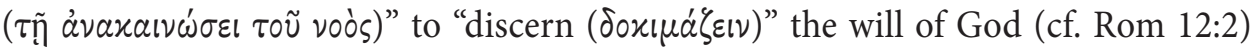
assumes a particular significance. Still in the light of the first chapter, there is a better understanding of the sense of the debated and difficult term $\lambda$ oylxós (Rom 12:1). In the criticism of the pagan worship (according to a tradition well attested in the Old Testament [cf. Isa 44; Wis 13-14]), the offering of the self to the true God in response to his mercy is something reasonable by contrast with the disordered mentality which addresses the lie (cf. Rom 1:21.25).

But there is more. If the result of the rebellion is impurity (axaAapoía)" and the dishonouring of the "bodies ( $\left.\sigma \omega^{\prime} \mu \alpha \tau \alpha\right)$ " (Rom 1:24), Paul exhorts his readers to offer their "bodies $\left(\sigma \omega^{\prime} \mu \alpha \tau \alpha\right)$ " (Rom 12:1), that is, their entire person. It follows from that that the undertone is ethical.

If we summarise the different points of contrast, we can represent the connection thus:

\begin{tabular}{|l|l|}
\hline \multicolumn{1}{|c|}{ Rom 1 } & \multicolumn{1}{c|}{ Rom 12 } \\
\hline Wrath of God (v. 18) & Mercy of God (v. 1) \\
\hline Refusal to worship and thank God (v. 21) & (Thanking) by offering a sacrifice (v. 1) \\
\hline Dishonouring the body (v. 24) & Presenting the body to God (v. 1) \\
\hline Impurity (v. 24) & Holiness (v. 1) \\
\hline Madness, idolatrous worship (vv. 21-23.25) & Reasonable worship (v. 1) \\
\hline Base mind (v. 28) & Renewed mind (v. 2) \\
\hline Refusal to recognise God (v. 28) & Discernment and obedience (v. 2) \\
\hline Decree of God (v. 32) & Will of God (v. 2) \\
\hline
\end{tabular}

These two passages, placed at the beginning of the two major sections of the letter, are not in clear contrast by chance. The correspondences do not seem to be there by pure coincidence.

As we have already observed, Paul employs the participle $\zeta \tilde{\omega} \sigma a v$, thus creating an oxymoron. Perhaps, however, the more satisfactory explanation comes from the relation between this term and chapter 6 where Paul exhorts:

So you too reckon yourselves to be dead to sin but living to God in Christ Jesus. Therefore, do not let sin reign in your mortal bodies to obey its desires, nor wish to present your members as weapons of injustice for sin but present yourselves to God as living from the dead, and your members as instruments of justice for God (Rom 6:11-13). 
In the light of this text, it appears again that Paul is not contrasting the Christian and Jewish forms of worship; rather, he is reflecting how the correct Christian orientation towards God contrasts with the insane idolatry which refuses to recognise and thank the Creator. Humanity in Christ is called to offer a worship that is fitting for the true God. In other words, it is by being dead to sin and obedient to God that Christians fulfil his will.

It would be quite wrong to fix the attention on the term $\lambda \alpha \tau p \varepsilon i \alpha$ alone. The brevity of the reference indicates that worship is not the subject about which Paul is speaking; nor does the apostle intend to deal with the form, the organisation and the practice of Christian worship. Rather, the term $\lambda \alpha \tau p \varepsilon i \alpha$ is a predicate or, better, a complement. Paul is presenting a holistic vision of life which he identifies with worship. In doing this, he widens the understanding of the type of worship valued by God. True worship is inseparably bound up with Christian behaviour. However, starting from this text, it would be erroneous to conclude that Paul is redefining worship by reducing it to Christian ethics. The whole of existence can be worship, but worship is not simply daily obedience. The concept of worship is wider than the specific vocabulary which Paul employs on this occasion and, more generally, in his letters.

To sum up, in Rom 12:1-2, Paul is not distancing himself from Jewish worship. The employment of cultic language in a non-cultic way epitomises what is found in some other passages of the Letter to the Romans (cf. Rom 1:9; 3:25; 15:16) and elsewhere (cf. Phil 2:17). In our text, Paul is not defining Christian worship over against its Jewish counterpart; rather, he is offering a vision of the Christian life as a whole. It is not isolated within an airtight compartment, separated from the times and places where worship is offered. Life itself becomes an act of offering, in particular a "reasonable" worship by contrast with the idolatry which rejects the Creator.

\section{Christian Worship}

If, then, Paul does not intend to oppose the two worships, Jewish and Christian, his words imply that, like the ancient Israel before them, the Christian believers should also be distinguished for their worship. The central point of the discourse is precisely this: Christian worship is conceived in a different way. It is far from being a spiritualisation of the worship. ${ }^{25}$ Such a reduction is excluded by the object of the sacrifice, "your bodies."

In this connection, Käsemann's thesis about the $\lambda \circ \gamma\left(x \grave{\eta} \lambda a \tau p \varepsilon i \alpha^{26}\right.$ has been fiercely challenged today. For the German exegete, the Pauline expression played a fun-

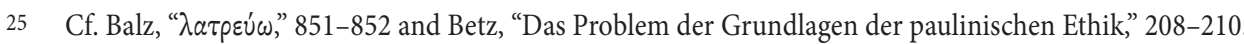

26 Cf. Käsemann, "Gottesdienst im Alltag der Welt (zu Rm 12)." 
damental role in the polemic against the Hellenistic worships some of which had undergone a process of interiorisation and spiritualisation in a mystical sense. ${ }^{27}$ Such an expression was intended to characterise the oratio infusa of praise rendered to the divinity as true worship on the part of a man filled with the Spirit and so representing the entire creation. In the two Hermetic texts quoted above, the $\lambda$ o $\gamma\llcorner x \dot{\eta}$ $\lambda a \tau p \varepsilon i \alpha$ indicates a type of intimist prayer, begun and ended within the individuality of the initiate. Käsemann interpreted these features in a Christian sense, affirming that the Holy Spirit acts in such a way as to make an individual who prays one of his instruments and spokesmen. ${ }^{28}$ However, this reading has been profoundly challenged: firstly, the texts referred to by Käsemann are late (the Corpus hermeticum is from the III century A.D.). Moreover, Käsemann appears to overlook the Old Testament background ${ }^{29}$; and it was the prophets who indicated that God was honoured not so much by means of ritual observance but by a genuine, spiritual, ethical and existential involvement (cf. Isa 1:10-16; 29:13; Mic 6:6-8). In other words, according to what is called the prophetic kérygma, worship cannot be separated from life (cf. Hos 6:6). God was seeking penitence, faith and obedience, above all in the reestablishment of justice and holiness within the Christian community.

Starting off against this background, it is understandable that Paul certainly does not refer to bloody sacrifices on the altars on the part of Christians; rather, it must be supposed that the apostle is indicating the nature of human existence in its physicality, as also the body as the means through which created beings enter into mutual communication. ${ }^{30}$ In other words, Paul has the courage to "secularise" cultic language, showing that the sacred space is not separated from existence, as if commandeered to be assigned for the sacrifice; rather, it corresponds to the daily activity, in the richness of human relations. Therefore, he is not developing any idea of replacement: instead, he is simply insisting on an existence which is pervaded entirely by the Holy Spirit and participates in the Christ event, coherent with faith and consequent upon it. ${ }^{31}$

27 Cf. the documentation concerning the philosophical polemic against the worship collected by R. Penna (L'ambiente storico-culturale delle origini cristiane, 151-152).

28 Cf. Käsemann, An die Römer, 316.

29 Cf. Peterson, "Worship and Ethics in Romans 12," 272-274.

30 Cf. Dunn, The Theology of Paul the Apostle, 543-544.

31 Hans Dieter Betz ("Das Problem der Grundlagen der paulinischen Ethik," 212) explains: "Die Benutzung dieser Opfersprache setzt den Apostel dazu in stand, zugleich praktisch und theologisch zu reden. Als

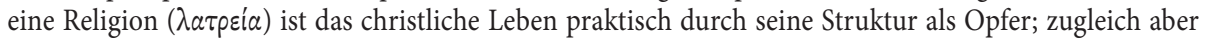
ist es ethisch, eschatologisch und der Vernunft zugänglich." 


\section{Conclusion}

If the pathway which we have followed makes any sense, it follows that, by breaking every semantic link bound up with the worship or sacrality and, instead, attributing to the expression $\lambda$ oүเxì $\lambda a \tau p \varepsilon i \alpha$ a secular semantic, it follows that Paul is operating in two directions. On the one hand, he avoids the trap of supersessionism with regard to the Jewish worship; on the other hand, he excludes a spiritualisation (or interiorisation) of Greek religious practices. In other words, Paul's language is distinct both from the great tradition of Israel in which he was born and from the Hellenistic world in which his proclamation runs its course. This is to say that the mystery of Christ is expressed in different languages but is prisoner of none because unique and highly individual. In one of the highest examples of his teaching, Paul shows how much he owes to two worlds but also how free he is from both in order to proclaim the Christian message.

Translated by Michael Tait

\section{Bibliography}

Aletti, J.-N., La Lettera ai Romani. Chiavi di lettura (Roma: Borla 2011).

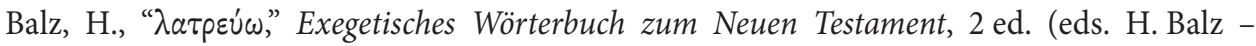
G. Schneider) (Stuttgart - Berlin - Köln: Kohlhammer 1992) II, 851-852.

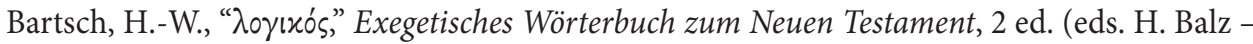
G. Schneider) (Stuttgart - Berlin - Köln: Kohlhammer 1992) 876-878.

Betz, H.D., "Das Problem der Grundlagen der paulinischen Ethik (Röm 12:1-2)," Zeitschrift für Theologie und Kirche 85 (1988) 199-218.

Blass, F. - Debrunner, A. - Rehkopf, F., Grammatik des neutestamentlichen Griechisch, 18 ed. (Göttingen: Vandenhoeck \& Ruprecht 2001).

Dunn, J.D.G., Beginning from Jerusalem (Christianity in the Making 2; Grand Rapids, MI Cambridge, UK: Eerdmans 2009).

Dunn, J.D.G., The Theology of Paul the Apostle (Grand Rapids, MI - Cambridge, UK: Eerdmans 1988).

Evans, C., "Romans 12.1-2: The True Worship," Dimensions de la vie chrétienne (Rm 12-13) (ed. L. De Lorenzi) (Serie monografica di "Benedictina". Sezione biblico-ecumenica 4; Rome: Abbaye de S. Paul 1979) 7-33.

Gupta, N.K., "What 'Mercies of God'? Oiktirmos in Romans 12:1 against Its Septuagintal Background," Bulletin for Biblical Research 22 (2012) 81-96.

Jodoin, D., "Rm 12, 1-2 une intrigue discursive. De loffrande des membres à l'offrande des corps," Études théologiques et religieuses 85 (2010) 499-512.

Käsemann, E., "Gottesdienst im Alltag der Welt (zu Rm 12)," Judentum Urchristentum Kirche. Festschrift für Joachim Jeremias (ed. W. Eltester) (Berlin: Töpelmann 1960) 165-171. 


\section{MATTEO CRIMELLA}

Käsemann, E., An die Römer (Handbuch zum Neuen Testament 8a; Tübingen: Mohr [Siebeck] 1973).

Marcato, M., Qual è la volontà di Dio (Rm 12:2b). Il discernimento cristiano nella lettera ai Romani (Supplementi alla Rivista biblica 53; Bologna: Dehoniane 2012).

Markschies, C., Hellenisierung des Christentums. Sinn und Unsinn einer historischen Deutungskategorie (Leipzig: Evangelische Verlagsanstalt 2012).

Moo, D.J., The Epistle to the Romans (New International Commentary on the New Testament; Grand Rapids, MI - Cambridge, UK: Eerdmans 1996).

Palinuro, M., "Rm 12:1-2: le radici dell'etica paolina,” Rivista biblica 52 (2004) 145-181.

Penna, R., Lambiente storico-culturale delle origini cristiane. Una documentazione ragionata, 4 ed. (La Bibbia nella storia 7; Bologna: Dehoniane 2000).

Penna, R., Lettera ai Romani. Introduzione, versione, commento. Volume unico (Scritti delle origini cristiane 6; Bologna: Dehoniane 2010).

Peterson, D., "Worship and Ethics in Romans 12," Tyndale House Bulletin 44 (1993) 271-288.

Pitta, A., L'evangelo di Paolo. Introduzione alle lettere autoriali (Graphé 7; Torino: Elledici 2013).

Pitta, A., Lettera ai Romani. Nuova versione, introduzione e commento, 3 ed. (I libri biblici. Nuovo Testamento 6; Milano: Paoline 2009).

Rodríguez Adrados, F., Historia de la lengua griega de los orígenes a nuestros días (Madrid: Gredos 1999).

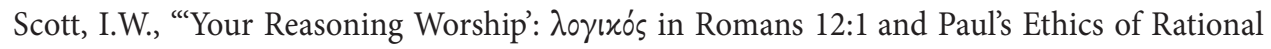
Deliberation," The Journal of Theological Studies 69 (2018) 500-532.

Smiga, G., "Romans 12:1-2 and 15:30-32," Catholic Biblical Quarterly 53 (1991) 268-270.

Thompson, M.B., "Romans 12.1-2 and Paul's Vision for Worship," A Vision for the Church. Studies in Early Christian Ecclesiology in Honour of J.P.M. Sweet (eds. M. Bockmuehl M.B. Thompson) (Edinburgh: Clark 1997) 121-132.

Usener, K., "Zur Sprache der Septuaginta," Septuaginta Deutsch. Erläuterungen und Kommentare zum griechischen Alten Testament. I. Genesis bis Makkabäer (eds. W. Kraus - M. Karrer) (Stuttgart: Deutsche Bibelgesellschaft 2011) 40-51. 